\title{
Luteolin Attenuates Dexamethasone-Induced Skeletal Muscle Atrophy in Male Albino Rats
}

\author{
NADIA HAWILA, M.Sc.; SABEHA HEDYA, M.D.; MAALY ABD ELMAABOUD, M.D. and \\ AMANY ABDIN, M.D.
}

The Department of Pharmacology, Faculty of Medicine, Tanta University, Egypt

\begin{abstract}
Background: Glucocorticoid-induced skeletal muscle atrophy is the most common type of drug-induced myopathy.

Aim of Study: This study was designated to investigate the effect of luteolin (Lut) on dexamethasone (Dex)-induced skeletal muscle atrophy in rats and the possible mechanisms of this effect.

Material and Methods: Forty male Wistar rats divided into; control group, Dex group, and 3 other groups that were treated by Lut $25 \mathrm{mg}, 50 \mathrm{mg}$ and $100 \mathrm{mg} / \mathrm{kg} /$ day; respectively for 14 days concomitantly with Dex. Body mass and muscle strength were recorded. Serum creatine kinase (CK) activity was assessed. Gastrocnemius muscle was weighed and processed for assay of tissue reduced glutathione (GSH), malondialdehyde (MDA) levels. Histopathological and immunohistochemical studies were carried out.

Results: Lut dose-dependently increased GSH, and crosssectional area (CSA), and decreased MDA and caspases-3 immunoreactivity. Lut in a dose $50 \mathrm{mg} / \mathrm{kg} /$ day improved the muscle mass and strength.

Conclusion: This study demonstrates that luteolin is a protective agent against glucocorticoid-induced atrophy through antioxidant and anti-apoptotic properties.
\end{abstract}

Key Words: Dexamethasone-Muscle atrophy - Luteolin.

\section{Introduction}

SKELETAL muscle atrophy is a loss of muscle mass due to an imbalance between protein synthesis and degradation in response to various conditions such as starvation, aging and disuse conditions like immobilization, denervation and unloading as well as a side effect of medications such as highdose glucocorticoids. It is characterized by decreased muscle fiber cross-sectional area (CSA), protein content and muscle strength leading weakness that impairs quality of life leading to falls and fractures $[\mathbf{1 , 2}]$.

\footnotetext{
Correspondence to: Dr. Nadia Hawila, E-Mail: nadia.maher@med.tanta.edu.eg nadiamaher063@gmail.com
}

Natural and synthetic glucocorticoids are widely prescribed for treatment and control of inflammatory and autoimmune diseases [3]. However, their chronic usage or elevated endogenous levels are associated with serious side effects, including hyperglycemia, osteoporosis and muscle atrophy which is characterized by body mass loss, weakness, and fatigue which limit their clinical use [4] Glucocorticoid-induced muscle atrophy is the most common type of drug-induced myopathy and it has been most often associated with fluorinated glucocorticoid preparations such as dexamethasone [5]

Glucocorticoid-induced muscle atrophy results from activation of catabolic pathways as ubiquitinproteosome and lysosomal pathways as well as suppression of anabolic pathways as insulin-like growth factor- $1 / \mathrm{AKT} / \mathrm{mammalian}$ target of rapamycin (IGF-1/AKT/mTOR) pathway that control muscle protein metabolism. Oxidative stress and apoptosis have been proved to play a role in its pathophysiology. Insulin resistance and the lowering of testosterone level also have a role [2,6-10] These pathways and mechanisms interact and modulate one another at different levels, coordinating the process of protein turn over.

Many natural and synthetic compounds have been studied for their protective effects on glucocorticoid-induced muscle atrophy such as growth factors, androgens, glutamine, creatine, betaadrenergic agonists, and taurine [11,12]. However, no drug was proved to be fully effective or free from adverse effects. Thus, this necessitates the introduction of new therapeutic agents to prevent or reverse muscle atrophy.

Luteolin, 3',4',5,7-tetrahydroxyflavone, is a common flavonoid present in edible plants, characterized by multiple biochemical and biological 
activities such as antioxidant and anti-apoptotic activities [13]. The effect of luteolin was tested in lipopolysaccharide-induced myotubes atrophy and revealed anti-atrophic effect through inhibition of atrogenes', Muscle Ring finger protein-1 (MuRF1) and Atrogin-1, expression [14]

The present study aimed to investigate the potential effect of luteolin on prevention or attenuation of dexamethasone-induced skeletal muscle atrophy in male rats and the possible mechanisms of this effect.

\section{Patients and Methods}

Drugs: Dexamethasone phosphate (Dex): Ampoules $(8 \mathrm{mg} / 2 \mathrm{ml})$, a product of AMRIYA Pharmaceutical Industries-Egypt, was diluted with normal saline to a final concentration of $1 \mathrm{mg} / \mathrm{ml}$. Luteolin (Lut): Yellow powder (HPLC 98\%), a product of Axinic labs, Oak Park, Australia, was dissolved in $0.5 \%$ carboxymethyl cellulose (CMC) to a final concentration of $10 \mathrm{mg} / \mathrm{ml}[15,16]$. Other chemicals used were of analytical grade.

Animals: Forty male Wistar rats (8-12 weeks old), weighing 150-200 g were used in this study. The animals were purchased from the official animal supplier of Faculty of Medicine, Tanta University. The study was carried out at the animal house of faculty of medicine, Tanta university in July 2018. Animals were housed in wire mesh cages under strict hygienic measures and had access to standard animal diet and water ad libitum and were allowed for acclimatization two weeks prior to the start of the experiment. The handling of animals and all experimental procedures were approved by the institutional "Research Ethics Committee, REC", Faculty of Medicine, Tanta University, Egypt (Approval no. \#31648/07/17).

Experimental design: After acclimatization, the rats were enrolled into 5 groups ( 8 for each) as follows: Group 1 (control group) received a vehicle of carboxymethylcellulose suspension $(0.5 \% \mathrm{CMC})$ orally and saline subcutaneously (S.C.) daily, group 2 (Dex group): Diseased group received Dex and oral CMC suspension daily, group 3 (Lut 25), group 4 (Lut 50) and group 5 (Lut 100) are diseased groups that received Dex and treated by oral 25 , $50,100 \mathrm{mg} / \mathrm{kg}$ of luteolin; respectively daily for 14 days concomitantly with dexamethasone. Muscle atrophy onset was induced by Dex administration by S.C. injection in the back of rats $(2 \mathrm{mg} / \mathrm{kg} /$ day $)$ for 2 weeks, depending on previous studies $[17,18]$ Doses of Lut were selected based on previous in vivo studies on Lut $[15,16]$ in rat models.
Body mass (BM): The initial and final body mass for each rat was recorded. Percent (\%) change of BM was calculated, equation.1.

$\%$ change in initial body mass $=\frac{\text { Final BM-Initial BM }}{\text { (Equation.1) }}$ Initial BM $\mathrm{X} 100$

Muscle strength measurement: At the 13 th day of the experiment, muscle strength was assessed by wire hanging test performed as following:

A $55 \mathrm{~cm}$ wide $2-\mathrm{mm}$ thick metallic wire is secured to two vertical stands, the wire is maintained $40 \mathrm{~cm}$ above a layer of bedding material to prevent injury to the animal when it falls. The wire must be tightly attached to the frame to avoid vibration or unwanted displacement of the wire while the investigator is handling the animals or during the measurements, since these unwanted effects would interfere with the animal's performance. Animals should hold by forelimb, but it is accepted to hold by four limbs at the start then counting should start after release of the hind limb and stops by falling of the animal or reaching maximum of 120 seconds holding the wire. Three trials are allowed for each animal with a 5 minutes inter-trial interval $[\mathbf{1 9 , 2 0}$. The results were represented as:

\section{A- Hang time (in seconds):}

The mean hanging time of the three trials is calculated to measure the hang time which is multiplied by animal weight at time of the test to calculate the holding impulse $\left(\mathrm{s}^{*} \mathrm{~g}\right)$.

\section{$B$ - Holding Impulse $\left(s^{*} g\right)$ :}

This reflects the tension (impulse) that the animal develops for maintaining itself on the wire, against gravity for the longest period, it diminishes the effect of body weight.

Holding Impulse $\left(\mathrm{s}^{*} \mathrm{~g}\right)=$ Hang Time $(\mathrm{sec}.) \mathrm{X}$ Body weight (grams).

Euthanasia and collection of samples: After 24 hours from the last treatment, rats were euthanized by diethyl ether, blood was collected by cardiac puncture, allowed to clot for 10-20 minutes at room temperature, then centrifuged for 20minutes at $3000 \mathrm{rpm}$, and serum was separated and preserved at $-80^{\circ} \mathrm{C}$ for further assessment of serum creatine kinase (CK) activity. Gastrocnemius muscles were dissected, one muscle was fixed in $10 \%$ formalin and processed for histopathological examination and immunohistochemistry, the other muscle was stored at $-80^{\circ} \mathrm{C}$ until prepared for the assessment of tissue GSH and MDA levels. 
Gastrocnemius muscle mass (grams) was recorded in each animal.

\section{Biochemical analysis:}

Serum CK activity (U/L) activity: Serum CK activity was measured by the colorimetric method by using BioChain's CK Assay Kit (Z5030048).

Tissue GSH levels: The assay of GSH levels (mg/g tissue) was performed using Biodiagnostic Kit (Cat. No GR 2511). It depends on the reduction of 5, 50-dithiobis-2-nitrobenzoic acid (DTNB) with glutathione to produce yellow color the absorbance of which is measured at $405 \mathrm{~nm}$.

Tissue lipid peroxidation (MDA levels): Lipid peroxidation was assessed by measuring tissue levels of MDA (nmol/g.tissue) in gastrocnemius muscle using a kit supplied by Biodiagnostic (Cat. No MD 2529), where the thiobarbituric acid reactive substances react with thiobarbituric acid to produce a pink colored complex, absorbance is read at $534 \mathrm{~nm}$.

Histopathological Examination of hematoxylin and eosin $(H \& E)$-stained sections: The right Gastrocnemius muscle was fixed in $10 \%$ formalin, embedded in paraffin, sections (3-4 m) atained with hematoxylin and eosin (H\&E) were used for examination of histopathological changes and measurement of the CSA Images were captured using Olympus Microscope BX41 connected to a digital camera Olympus DP25. Over 40 myofibers/ field from at least five different high power fields (x 400 magnification) were delineated manually and fiber CSA was measured by using Image $\mathbf{J}$ software (National Institute of Health, Bethesda, Maryland, USA) and the average was calculated for each group [21].

Immunohistochemistry: Immunohistochemical expression of caspases-3 in the right gastrocnemius muscle was assessed using Rabbit Anti-Human caspases-3 Monoclonal Antibody (Clone EP36) purchased from MASTER DIAGNOSTICA, Granada, Spain, according to the method of Gown and Willingham [22]. The slides were visualized under a light microscope. Caspase-3 immunoreactivity appears as brownish cytoplasmic discoloration.

Statistical analysis: Analysis of the numerical values was performed using (Graph Pad Prism version 5 for Windows, 2007, Graph Pad software, Inc.) Data were expressed as mean \pm standard deviation (SD). Results were tested for normality by Shapiro-Wilk test. Multiple comparisons were performed using One-Way ANOVA followed by
Tukey, a post Hoc test. The 0.05 level of probability was used as the criterion for significance $(p<0.05)$.

\section{Results}

Alterations in body mass (BM) and gastrocnemius muscle mass:

By the end of the experiment, the BM of the control group increased by about $29 \%$ of the initial mass. While BM of the Dex group was significantly decreased as compared to the control group by $27 \%$ of the initial mass $(p<0.001)$. Lut-treated groups showed non-significant change of $\mathrm{BM}$ as compared to Dex group ( $p>0.05)$, (Fig. 1A).

The gastrocnemius muscle mass of the Dex group was significantly reduced as compared to the control group $(p<0.001)$. Lut 50 group showed a significant increase in muscle mass, $(p<0.01)$. Meanwhile, Lut 25 and Lut 100 groups showed non-significant improvement in muscle mass $(p>0.05)$, (Fig. 1B).

Histopathological examination of $H \& E$-stained sections and CSA:

Atrophic changes were observed in the Dex group as reduction and marked variation in fiber diameters, with an increased number of the nuclei and loss of the characteristic polygonal appearance of fibers found in the control group, (Fig. 2A,B). In addition, myofiber CSA was significantly reduced as compared to the control group $(p<0.001)$, (Fig. 3). Whereas in Lut-treated groups, there was a dose-dependent improvement of the histopathological changes (Fig. 2C,D,E), in addition to a significant dose-dependent increase in CSA, (Fig. $3),(p<0.001)$.

Effects on forelimb muscle strength (Hang time and Holding impulse):

There was a significant reduction of forelimb muscle strength in the Dex group as compared to the control group $(p<0.001)$, demonstrated as a significant reduction in hang time and holding impulse. In Lut 50 group, forelimb muscle strength was not significantly reduced as compared to Dex group $(p<0.001)$, demonstrated as a significant increase in hang time and holding impulse (Fig. 4 A,B); respectively. Lut 25 and Lut 100 groups showed non-significant improvement in muscle strength as compared to Dex group, $(p>0.05)$.

\section{Effects on tissue levels of GSH and MDA:}

GSH levels were significantly reduced while MDA levels were significantly increased in the Dex group as compared to the control group 
$(p<0.001)$. In Lut 50 and Lut 100 groups, tissue GSH levels were not significantly decreased and MDA levels were not significantly increased as compared to Dex group $(p<0.001)$, (Fig. 5A,B); respectively.

Caspase-3 Immunohistochemistry (a marker of apoptosis), Serum CK activity (a marker of myotoxicity):

Dex group showed a significant increase in caspases-3 immunoreactivity as compared to the

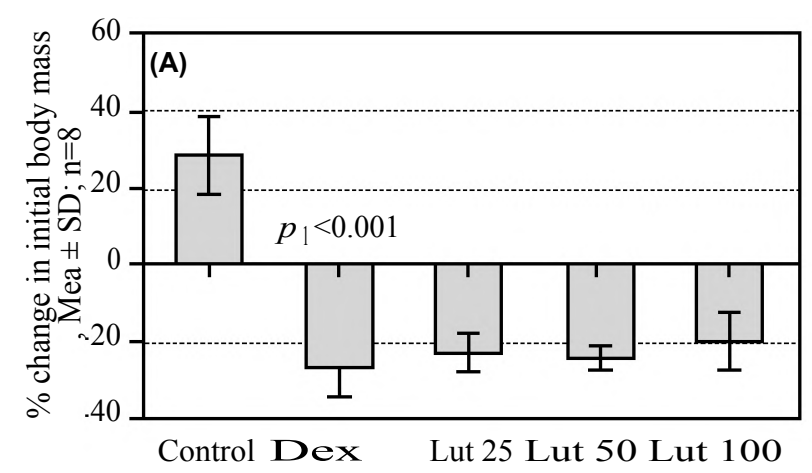

control group, (Fig. 6A,B). In Lut-treated groups, rise in caspases-3 immunoreactivity was prevented in a dose-dependent reduction in, (Fig. 6C,D,E).

Serum CK activity in the Dex group showed a significant reduction as compared to the control group $(p<0.001)$. Lut 50 and Lut 100 groups showed a significant reduction in serum CK activity as compared to the Dex group $(p<0.001)$, (Fig. 7).

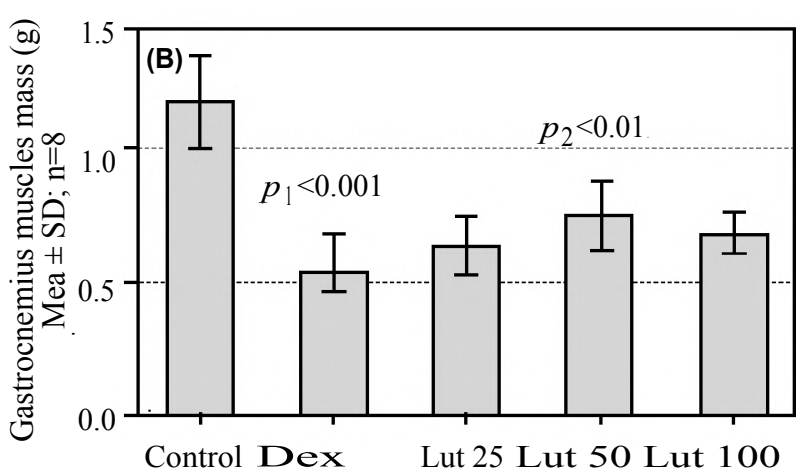

Fig. (1): Percentage (\%) change of initial body mass (A) and gastrocnemius mass (g) (B). Values are expressed as mean \pm SD. Dex: Dexamethasone.

Lut 25: Luteolin $25 \mathrm{mg} / \mathrm{kg} /$ day + dexamethasone. Lut 50: Luteolin $50 \mathrm{mg} / \mathrm{kg} /$ day + dexamethasone. Lut 100: Luteolin $100 \mathrm{mg} / \mathrm{kg} /$ day + dexamethasone. $\mathrm{n}=$ Number.
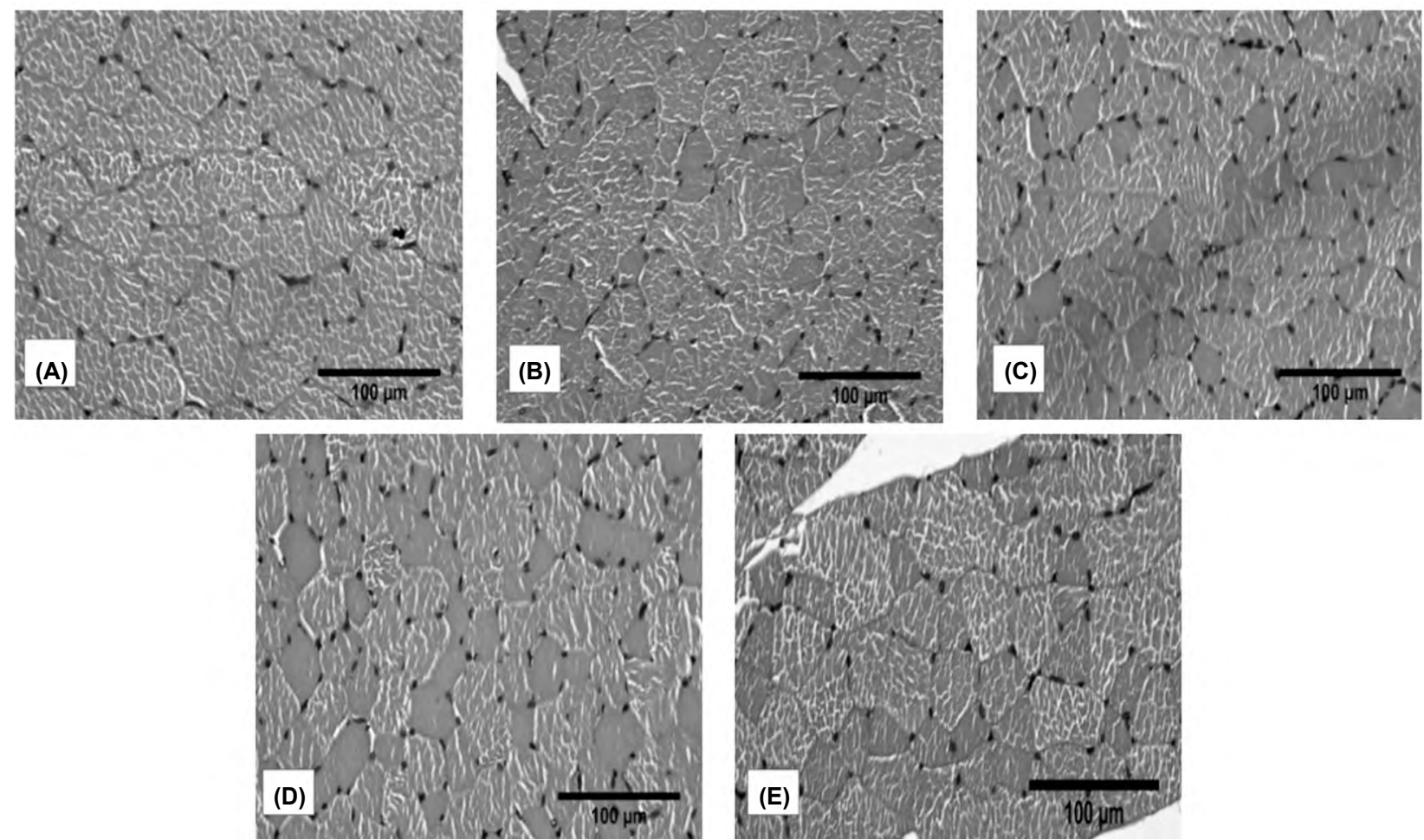

Fig. (2): Effects on gastrocnemius muscle histopathology (H\&E X400) (A-E).

(A): Control group showing the polygonal fibers with peripheral myonuclei. (B): Dex group showing hypereosinophilic muscle fibers of reduced diameter and increased nuclei. (C): Lut 25 group showing hypereosinophilic muscle fibers with moderate variation in size. (D): Lut 50 group showing polygonal muscle fibers with moderate variation in size. (E): Lut 100 group showing polygonal muscle fibers with minimal variation in size and peripheral nuclei. Scale bar=100 me 


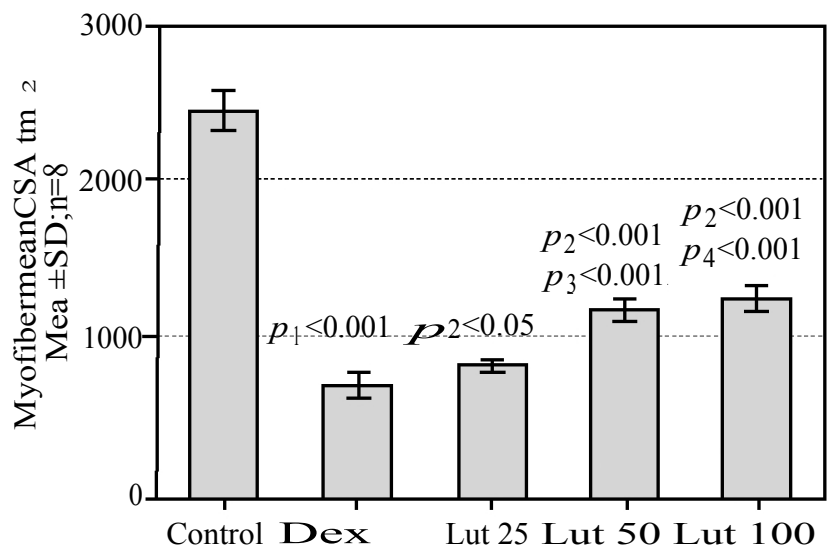

Fig. (3): Effects on gastrocnemius myofiber cross-sectional area CSA (

Values are expressed as mean $\pm \mathrm{SD}$.

CSA : Cross-sectional area.

Dex: : Dexamethasone.

Lut 25 : Luteolin $25 \mathrm{mg} / \mathrm{kg} / \mathrm{day}+$ dexamethasone.

Lut 50 : Luteolin $50 \mathrm{mg} / \mathrm{kg} /$ day + dexamethasone.

Lut $100:$ Luteolin $100 \mathrm{mg} / \mathrm{kg} /$ day + dexamethasone.

$\mathrm{n} \quad$ : Number.

One-way ANOVA (Tukey test):

- p1: Group 2 (Dex) vs. group 1 (Control).

- p2: Group 3 (Lut 25), group 4 (Lut 50), and group 5 (Lut 100) vs. group 2 (Dex).

-p3: Group 4 (Lut 50) vs. Group 3 (Lut 25).

- p4: Group 5 (Lut 100) vs. group 3 (Lut 25).
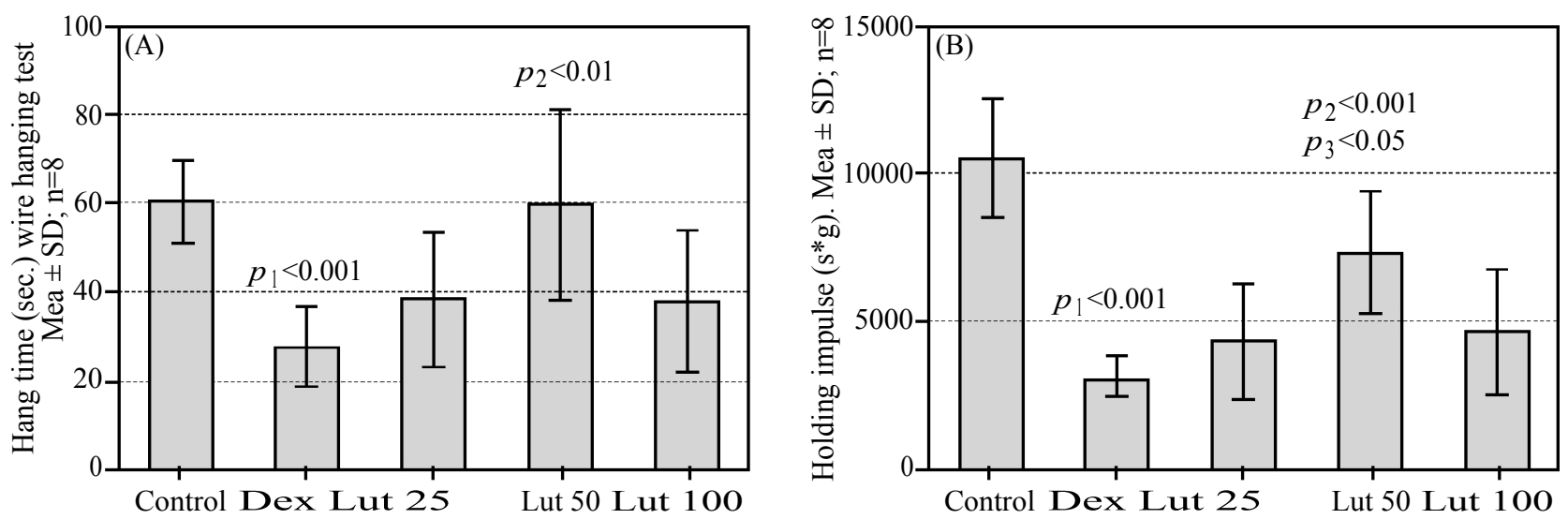

Fig. (4): Effects on muscle strength (Hanging wire test) (A): Hang time (sec.) and (B): Holding impulse (s*g).

$$
\begin{aligned}
& \text { Values are expressed as mean } \pm \mathrm{SD} \text {. } \\
& \text { Dex } \quad: \text { Dexamethasone. } \\
& \text { Lut } 25: \text { Luteolin } 25 \mathrm{mg} / \mathrm{kg} / \text { day + dexamethasone. } \\
& \text { Lut } 50: \text { Luteolin } 50 \mathrm{mg} / \mathrm{kg} / \text { day + dexamethasone. } \\
& \text { Lut } 100: \text { Luteolin } 100 \mathrm{mg} / \mathrm{kg} / \text { day + dexamethasone. } \\
& \mathrm{n} \quad: \text { Number, One-way. }
\end{aligned}
$$

ANOVA (Tukey test):

- p1: Group 2 (Dex) vs. group 1 (Control).

- p2: Group 4 (Lut 50) vs. group 2 (Dex).

- p3: Group 4 (Lut 50) vs. Group 3 (Lut 25).
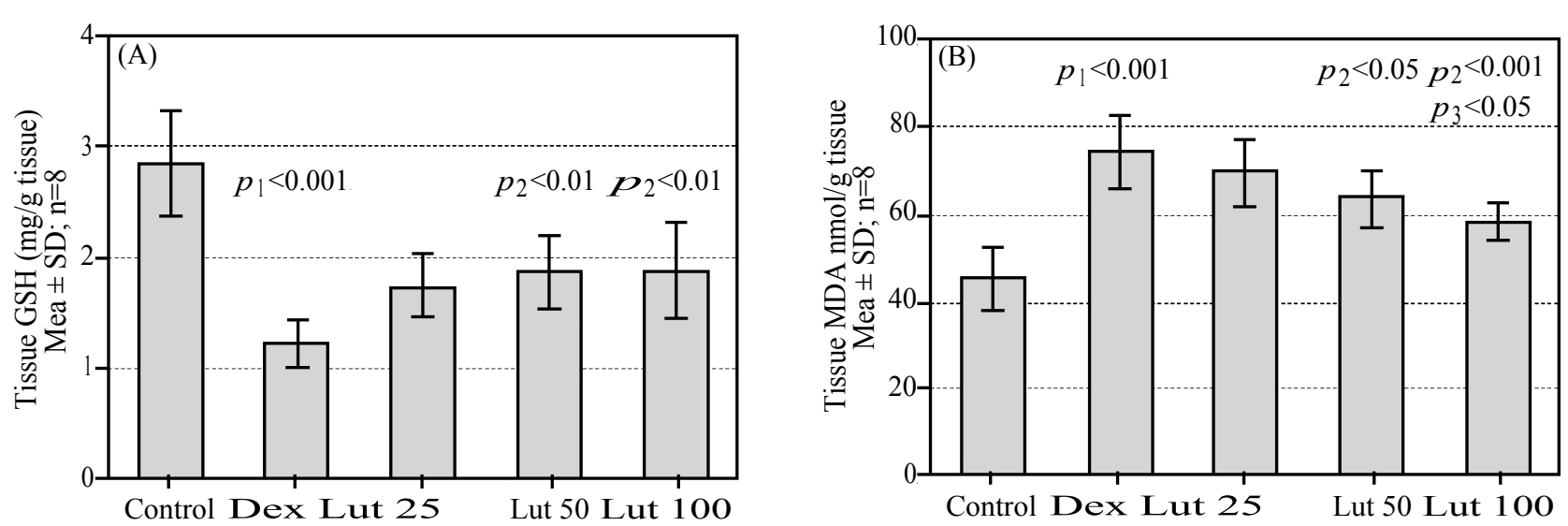

Fig. (5): Effects on GSH levels (mg/g tissue) (A), and MDA levels (nmol/g tissue) (B) in gastrocnemius muscle tissue.

Values are expressed as mean \pm SD.

Dex : Dexamethasone.

GSH : Reduced glutathione.

Lut $25+$ Dex : Luteolin $25 \mathrm{mg} / \mathrm{kg} /$ day + dexamethasone.

Lut $50+$ Dex : Luteolin $50 \mathrm{mg} / \mathrm{kg} /$ day + dexamethasone.

Lut100 + Dex : Luteolin $100 \mathrm{mg} / \mathrm{kg} / \mathrm{day}+$ dexamethasone.

MDA : Malondialdehyde.

$\mathrm{n} \quad$ : Number.
One-way ANOVA (Tukey test):

- p1: Group 2 (Dex) vs. group 1 (Control).

- p2: Group 4 (Lut 50), and group 5 (Lut 100) vs. group 2 (Dex).

- p3: Group 5 (Lut 100) vs. group 3 (Lut 25). 

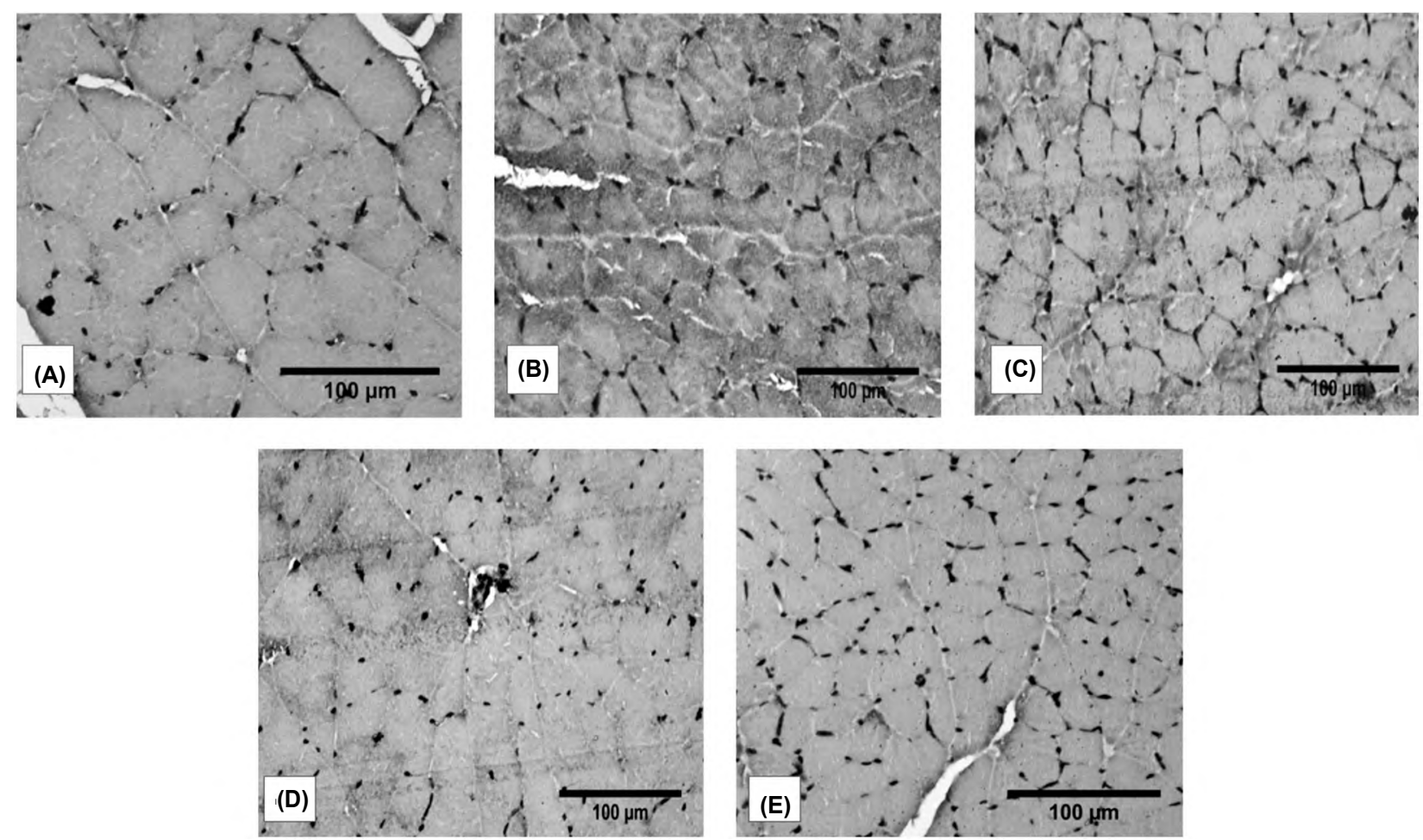

Fig. (6): Effects on gastrocnemius muscle caspases-3 immunoreactivity (X400) (A-E).

(A): Control group showed very mild positive brownish immunoreactions for caspase-3 in some muscle fibers. (B): Dex group showed strong positive brownish coloration of the cytoplasm of almost all fibers indicating highly positive immunoreactivity. Lut dose-dependently and significantly reduced these Dex-induced increases in caspase 3 immunoreactive muscle fibers. (C): Lut 25 group. (D): Lut 50 group. (E): Lut 100 group. Scale bar=100 me

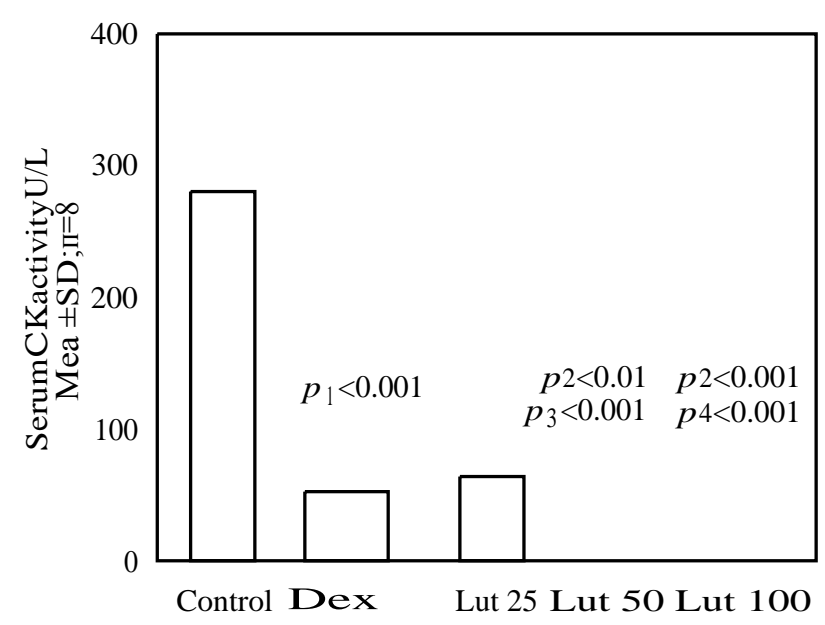

Fig. (7): Effect on Serum CK activity (U/L).

\footnotetext{
Values are expressed as mean $\pm \mathrm{SD}$

CK : Creatine kinase.

Dex : Dexamethasone.

Lut 25 : Luteolin $25 \mathrm{mg} / \mathrm{kg} / \mathrm{day}+$ dexamethasone.

Lut 50 : Luteolin $50 \mathrm{mg} / \mathrm{kg} / \mathrm{day}+$ dexamethasone.

Lut1 00 : Luteolin $100 \mathrm{mg} / \mathrm{kg} / \mathrm{day}+$ dexamethasone.

$\mathrm{n} \quad$ : Number.

One-way ANOVA (Tukey test):

- p1: Group 2 (Dex) vs. group 1 (Control).

- p2: Group 4 (Lut 50), and group 5 (Lut 100) vs. group 2 (Dex).

- p3: Group 4 (Lut 50) vs. Group 3 (Lut 25).

- p4: Group 5 (Lut 100) vs. group 3 (Lut 25).
}

\section{Discussion}

The present study investigated the effect of luteolin on dexamethasone-induced skeletal muscle atrophy in rats and the possible mechanisms of this effect. We concluded that Lut has partly prevented Dex-induced atrophy via antioxidant and antiapoptotic activities.

In this study, Dex injection lead to body mass loss, may be due to its catabolic and growth suppressing effects in addition to anorexigenic effect [23]. Body mass was not increased by Luteolin. Although, some studies have shown that luteolin can increase body mass or prevent body mass loss in some diseases like diabetes [24], and cancer [25] Failure to improve body mass in this study may be attributed to the intense catabolism induced by a high dose of Dex which could not be overcome by luteolin or due to the Dex-induced anorexigenic effect or Dex-Lut interaction.

The reduction of the gastrocnemius muscle mass and the reduction of muscle strength in the Dex group indicate the catabolic action that results from the activation of proteolytic pathways and suppression of the anabolic ones $[26,27]$. In the 
current study, dexamethasone decreased forelimb muscles' strength as reported earlier [28, 29]. Only Lut $50 \mathrm{mg} / \mathrm{kg} /$ day $\mathrm{mg}$ prevented significant decrease in muscle strength shown as increased hang time and holding impulse. Other doses could not improve it.

H \& E- stained sections of gastrocnemius muscle from Dex group showed marked variation of fiber size, irregular nuclear arrangement, loss of the characteristic polygonal appearance of myofibers, and no inflammatory infiltrate, which are characteristic changes of muscle atrophy $[17,30]$ CSA of muscle fibers was reduced confirming the catabolic effect of dexamethasone as proved in previous studies [31,32]. In Lut-treated groups, atrophic changes were reduced in a dose-dependent manner as compared to Dex group. It is noteworthy that Lut $100 \mathrm{mg} / \mathrm{kg} /$ day was superior to the other doses in improving the histologic picture, but unexpectedly, this was not reflected on muscle strength. This may be attributed to modulations in the different pathways that affect muscle action and muscle growth.

Oxidative stress was proved to take part in the pathogenesis of muscle atrophy [8]. Dexamethasone, among different glucocorticoids, has deleterious effects on redox status and mitochondrial function resulting in a state of oxidative stress that affects various tissues [9]. In this study, GSH level was reduced, and tissue MDA level was increased in the Dex group indicating oxidative stress status that may explain the existing atrophy as proved earlier [25]. GSH was increased and MDA was decreased in Lut 50 and Lut 100 groups but not in Lut 25 group. These results confirm the proved antioxidant effect of luteolin [33] and possibly contributed to its protective effect against Dexinduced atrophy.

The contribution of apoptosis to the present atrophy was confirmed by the marked increase in caspase-3 immunoreactivity in immune-stained gastrocnemius muscle sections from Dex group, as proved previously [34]. Apoptosis is implicated as one of the mechanisms of different types of muscle atrophy through activation of various caspases [35] such as caspases-3 assisting in protein degradation $[36,37]$. Lut significantly prevented increase in caspase- 3 immunoreactivity in a dosedependent manner and this is in agreement with studies which proved the anti-apoptotic properties of luteolin $[33,38]$

$\mathrm{CK}$ is an intracellular enzyme expressed in various tissues as skeletal, cardiac muscles, and brain, the elevation of its serum level indicates tissue damage, it is considered as a marker of cytotoxicity [39]. In our study, serum CK activity did not increase in Dex group, conversely, it decreased below its activity in the control group and this is inconsistent with common features of muscle disease and Dex-induced catabolic state $[\mathbf{2 8 , 4 0}$ However, some studies showed that it can be decreased by glucocorticoids through protein synthesis inhibition, cellular membrane stabilization, anti-inflammatory, and catabolic effects on myofibers $[\mathbf{1 7 , 4 1}]$. Because steroid myopathy is not caused by inflammatory cells invasion or myofibers destruction but results from the catabolism of muscle proteins, it is accepted that serum CK does not increase [17]. Luteolin; however, caused significant lowering of CK activity in Lut 50 and Lut 100 groups which would be due to inhibition of enzyme leakage as encountered in cardiac muscle injury via inhibition of intracellular oxidative stress and $\mathrm{Ca}^{2}+$ overload and maintaining membrane integrity preventing enzyme leakage [42]. Also, Lut administration may have decreased $\mathrm{CK}$ activity by direct enzyme inhibition [43].

\section{Conclusion:}

From this study we can conclude that Lut can attenuate Dexamethasone induced skeletal muscle atrophy via antioxidant and anti-apoptotic mechanisms.

Authors recommend investigating other mechanisms of the antiatrophic effect of luteolin specially the effect on signaling pathways of muscle atrophy and the effect on gene expression in the different models of atrophy.

\section{Acknowledgments:}

Special thanks to Dr. Shaimaa M. Badr (shaimaa.badr@med.tanta.edu.eg) lecturer of Histology, Faculty of Medicine, Tanta University, for her cooperation in carrying out the histopathological, Immunohistochemical examination and helping us in photo-imaging and in finalizing this work.

\section{References}

1- KANDARIAN S.C. and JACKMAN R.W.: Intracellular signaling during skeletal muscle atrophy. Muscle \& Nerve, 33 (2): 155-165, 2006.

2- SCHAKMAN O., GILSON H. and THISSEN, J.-P.: Mechanisms of glucocorticoid-induced myopathy. Journal of Endocrinology, 197 (1): 1-10, 2008.

3- COUTINHO A.E. and CHAPMAN K.E.: The antiinflammatory and immunosuppressive effects of glucocorticoids, recent developments and mechanistic insights Molecular and Cellular Endocrinology, 335 (1): 2-13, 2011. 
4- SCHÄCKE H., DÖCKE W.-D. and ASADULLAH K.: Mechanisms involved in the side effects of glucocorticoids. Pharmacology \& Therapeutics, 96 (1): 23-43, 2002.

5- PEREIRA R.M.R. and DE CARVALHO J.F.: Glucocorticoid-induced myopathy. Joint Bone Spine, 78 (1): 41-44, 2011.

6- DU J., WANG X., MIERELES C., BAILEY J.L., DEBIGARE R., ZHENG B. and MITCH W.E.: Activation of caspase-3 is an initial step triggering accelerated muscle proteolysis in catabolic conditions. The Journal of Clinical Investigation, 113 (1): 115-123, 2004.

7- DOLATABADI A.A. and ZARCHII S.R.: The effect of prescription of different Dexamethasone doses on reproductive system. Biomedical Research, 26 (4), 2015.

8- CHOI M.H., OW J.R., YANG N.-D. and TANEJA R.: Oxidative stress-mediated skeletal muscle degeneration: molecules, mechanisms, and therapies. Oxidative Medicine and Cellular Longevity, 2016.

9- TANG V.M.: Glucocorticoid effects on oxidative stress and mitochondrial dysfunction. University of British Columbia, 2012.

10-WANG X., HU Z., HU J., DU J. and MITCH W.E.: Insulin resistance accelerates muscle protein degradation: activation of the ubiquitin-proteasome pathway by defects in muscle cell signaling. Endocrinology, 147 (9): 4160-4168, 2006.

11- SCHAKMAN O., KALISTA S., BARBE C., LOUMAYE A. and THISSEN J.-P.: Glucocorticoid-induced skeletal muscle atrophy. The International Journal of Biochemistry \& Cell Biology, 45 (10): 2163-2172, 2013.

12- YOSHIOKA Y., KUBOTA Y., SAMUKAWA Y., YAMASHITA Y. and ASHIDA H.: Glabridin inhibits dexamethasone-induced muscle atrophy. Archives of Biochemistry and Biophysics, 664: 157-166, 2019.

13- LIN Y., SHI R., WANG X. and SHEN H.-M.: Luteolin, a flavonoid with potential for cancer prevention and therapy. Current cancer drug targets, 8 (7): 634-646, 2008.

14- SHIOTA C., ABE T., KAWAI N., OHNO A., TESHIMAKONDO S., MORI H. and NIKAWA T.: Flavones inhibit LPS-induced atrogin-1/MAFbx expression in mouse C2C12 skeletal myotubes. Journal of nutritional science and vitaminology, 61 (2): 188-194, 2015.

15- NAI C., XUAN H., ZHANG Y., SHEN M., XU T., PAN D. and LI D.: Luteolin Exerts Cardioprotective Effects through Improving Sarcoplasmic Reticulum Ca2. Evidence-Based Complementary and Alternative Medicine, 2015.

16- TANG L., DENG B., SHI L., WEI B., REN B. and FU X.: Effect of Luteolin on 11 beta-hydroxysteroid dehydrogenase in rat liver and kidney. Evidence-Based Complementary and Alternative Medicine, 2015.

17- KONNO S.: Hydroxyl radical formation in skeletal muscle of rats with glucocorticoid-induced myopathy. Neurochemical Research, 30 (5): 669-675, 2005.

18- MORIMOTO Y., KONDO Y., KATAOKA H., HONDA Y., KOZU R., SAKAMOTO J. and OKITA M.: Heat treatment inhibits skeletal muscle atrophy of glucocorticoid-induced myopathy in rats. Physiological Research, 64 (6): 897-905, 2015.
19- MURPHY M., RICK J.T., MILGRAM N. and IVY G.: A simple and rapid test of sensorimotor function in the aged rat. Neurobiology of Learning and Memory, 64 (2): 181186, 1995.

20- VAN PUTTEN M., AARTSMA-RUS A. and LOUVAINLA-NEUVE L.: The use of hanging wire tests to monitor muscle strength and condition over time. TREAT-NMD Neuromuscular Network, 4: 1-12, 2016.

21- MOSAAD S.M., ZAITONE S.A., IBRAHIM A., EL-BAZ A.A., ABO-ELMATTY D.M. and MOUSTAFA Y.M.: Celecoxib aggravates cardiac apoptosis in L-NAMEinduced pressure overload model in rats: Immunohistochemical determination of cardiac caspase-3, Mcl-1, Bax and Bcl-2. Chemico-biological Interactions, 272: 92-106, 2017.

22- GOWN A.M. and WILLINGHAM M.C.: Improved detection of apoptotic cells in archival paraffin sections: immunohistochemistry using antibodies to cleaved caspase 3. Journal of Histochemistry \& Cytochemistry, 50 (4): 449-454, 2002.

23- ROOMAN R., KOSTER G., BLOEMEN R., GRESNIGT R. and VAN BUUL-OFFERS S.: The effect of dexamethasone on body and organ growth of normal and IGF-IItransgenic mice. Journal of Endocrinology, 163 (3): 543$552,1999$.

24- ZHANG Y., TIAN X.-Q., SONG X.-X., GE J.-P. and XU Y.-C.: Luteolin protect against diabetic cardiomyopathy in rat model via regulating the AKT/GSK-3 $\alpha$ signalling pathway. Biomedical Research, 28 (3): 1359-1363, 2017.

25- CHEN T., LI B., XU Y., MENG S., WANG Y. and JIANG Y.: Luteolin reduces cancer-induced skeletal and cardiac muscle atrophy in a Lewis lung cancer mouse model. Oncology Reports, 2018.

26- ROY R., GARDINER P., SIMPSON D. and EDGERTON V.: Glucocorticoid-induced atrophy in different fibre types of selected rat jaw and hind-limb muscles. Archives of Oral Biology, 28 (7): 639-643, 1983.

27- MITCH W.E. and GOLDBERG A.L.: Mechanisms of muscle wasting-the role of the ubiquitin-proteasome pathway. New England Journal of Medicine, 335 (25): 1897-1905, 1996.

28- NOH K.K., CHUNG K.W., CHOI Y.J., PARK M.H., JANG E.J., PARK C.H. and CHUNG H.Y.: 3 -Hydroxy (3-Methylbutyrate Improves Dexamethasone-Induced Muscle Atrophy by Modulating the Muscle Degradation Pathway in SD Rat. PLoS One, 9 (7): e102947, 2014.

29- ALEV K., VAIN A., ARU M., PEHME A., PURGE P., KAASIK P. and SEENE T.: Glucocorticoid-induced changes in rat skeletal muscle biomechanical and viscoelastic properties: aspects of aging. Journal of Manipulative \& Physiological Therapeutics, 41 (1): 19-24, 2018.

30- KIM J.W., KU S.-K., HAN M.H., KIM K.Y., KIM S.G., KIM G.-Y. and CHOI Y.H.: The administration of Fructus Schisandrae attenuates dexamethasone-induced muscle atrophy in mice. International Journal of Molecular Medicine, 36 (1): 29-42, 2015.

31- UMEKI D., OHNUKI Y., MOTOTANI Y., SHIOZAWA K., SUITA K., FUJITA T. and OKUMURA S.: Protective effects of clenbuterol against dexamethasone-induced masseter muscle atrophy and myosin heavy chain transition. PLoS One, 10 (6): e0128263, 2015. 
32- YAMAMOTO D., MAKI T., HERNINGTYAS E.H., IKESHITA N., SHIBAHARA H., SUGIYAMA Y. and TAKAHASHI Y.: Branched-chain amino acids protect against dexamethasone-induced soleus muscle atrophy in rats. Muscle \& Nerve: Official Journal of the American Association of Electrodiagnostic Medicine, 41 (6): 819-827, 2010.

33- ZHANG T., WU W., LI D., XU T., ZHU H., PAN D. and LIU Y.: Anti-oxidant and anti-apoptotic effects of luteolin on mice peritoneal macrophages stimulated by angiotensin II. International Immunopharmacology, 20 (2): 346-351, 2014.

34- LIM J.M., LEE Y.J., CHO H.R., PARK D.C., JUNG G.W., KU S.K. and CHOI J.S.: Extracellular polysaccharides purified from Aureobasidium pullulans SM-2001 (Polycan) inhibit dexamethasone-induced muscle atrophy in mice. International Journal of Molecular Medicine, 41 (3): 12451264, 2018.

35- DALLA LIBERA L., ZENNARO R., SANDRI M., AMBROSIO G.B. and VESCOVO G.: Apoptosis and atrophy in rat slow skeletal muscles in chronic heart failure. American Journal of Physiology-Cell Physiology, 277 (5): C982-C986, 1999.

36- LEE M.-C., WEE G.-R. and KIM J.-H.: Apoptosis of skeletal muscle on steroid-induced myopathy in rats. The Journal of Nutrition, 135 (7): 1806S-1808S, 2005.

37- DIRKS-NAYLOR A.J. and GRIFFITHS C.L.: Glucocorticoid-induced apoptosis and cellular mechanisms of myopathy. The Journal of Steroid Biochemistry and Molecular Biology, 117 (1-3): 1-7, 2009.
38- JIANG Q., PAN D., YANG Y., HU Y., FANG L., SHANG P. and LI D.: Luteolin Regulates Macrophage Polarization via the PI3K/Akt Pathway to Inhibit the Apoptosis Stimulated by Angiotensin II. Current Pharmaceutical Biotechnology, 19 (5): 428-437, 2018.

39- HESS J.W., MACDONALD R.P., FREDERICK R.J., JONES R.N., NEELY J. and GROSS D.: Serum creatine phosphokinase (CPK) activity in disorders of heart and skeletal muscle. Annals of Internal Medicine, 61 (6): 1015-1028, 1964.

40- ZHANG Y., HUANG J.-J., WANG Z.-Q., WANG N. and WU Z.-Y.: Value of muscle enzyme measurement in evaluating different neuromuscular diseases. Clinica Chimica Acta., 413 (3-4): 520-524, 2012.

41- GOTO H., BENSON K.T., KATAYAMA H., TONOOKA M., TILZER L.L. and ARAKAWA K.: Effect of highdose of methylprednisolone on tourniquet ischaemia. Canadian Journal of Anaesthesia, 35 (5): 484-488, 1988.

42- WANG S.-Q., HAN X.-Z., LI X., REN D.-M., WANG X.-N. and LOU H.-X.: Flavonoids from Dracocephalum tanguticum and their cardioprotective effects against doxorubicin-induced toxicity in $\mathrm{H} 9 \mathrm{c} 2$ cells. Bioorganic \& Medicinal Chemistry Letters, 20 (22): 6411-6415, 2010.

43- MIURA T., MURAOKA S. and FUJIMOTO Y.: Inactivation of creatine kinase induced by quercetin with horseradish peroxidase and hydrogen peroxide: Pro-oxidative and anti-oxidative actions of quercetin. Food and Chemical Toxicology, 41 (6): 759-765, 2003. 


\section{عقار اللوتيولين يقلل من ضمور العضلات الهيكلية المستحث بالديكساميثازون في ذكور فور الجرذان البيضاء}

المقدمة: ضمود العضلات الهيكية هو نقدان كتلة العضلات نتيجة عدم التوانن بين تخليق البرتين وتكميره إستجابة لظروف مختلفة.

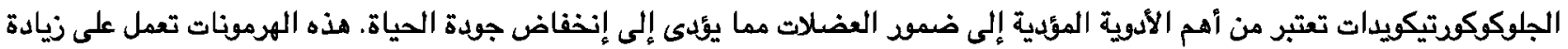

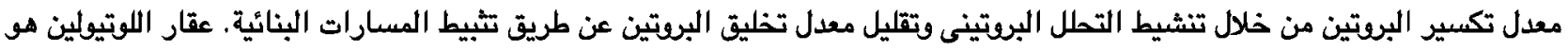

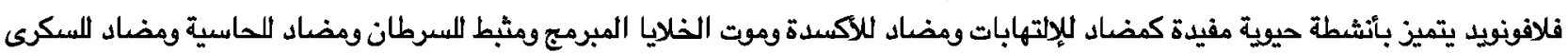

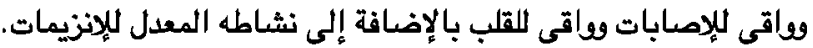

الهدف من الدراسة: هو التحقق من وجود تأثير محتمل اللوتيولين على ضمق العضلات المستحث بالديكساميثّاننف فى الجرذان والكشف عن الآليات الممكنة لهذا التأثير .

مواد وطرق البحث: تم تنقيذ الدراسة على ذكو الجرذان البيضاء تم تقسيم الحيوانات إلى ه مجموعات مثساوية (1 جرذان لكل مجموعة)

$$
\begin{aligned}
& \text { - مجموعة ا: مجموعة ضابطة + محلول ملحى + كاربوكسى ميثيل سيليولوز. } \\
& \text { - مجموعة Y: ديكساميثازنف + كاربوكسى ميثيل سيليولوذ. } \\
& \text { - مجموعة ب: ديكساميثانون + لوتيولين جرعة صغيرة (0 مجم/كجم). }
\end{aligned}
$$

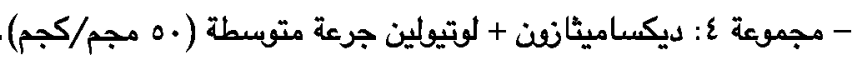

$$
\begin{aligned}
& \text { - مجموعة ه: ديكساميثانفن + لوتيولين جرعة كبيرة ( . . } 1 \text { مجم/كجم). }
\end{aligned}
$$

تم إعطاء الأدوية للحيوانات بشكل يومى حتى نهاية الدراسة فى اليوم الرابع عشر وتم تقييم أوذان الحيوانات فى بداية ونهاية التجرية.

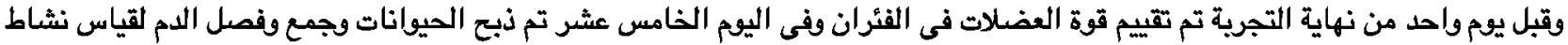

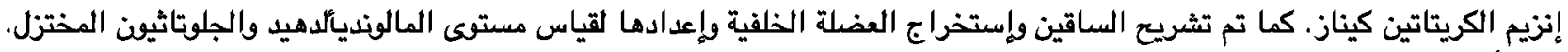

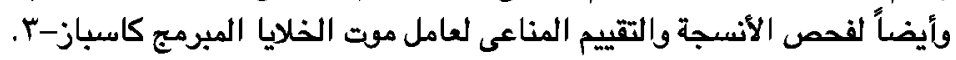

النتائج: أدى عقار الديكساميثانفن إلى إنخفاض ذنى دلالة إحصائية في ونن الفئران وكتلة العضلات الهيكية وقوة العضلة وحجم الخلايا

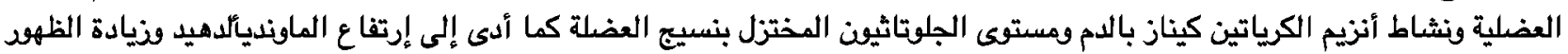

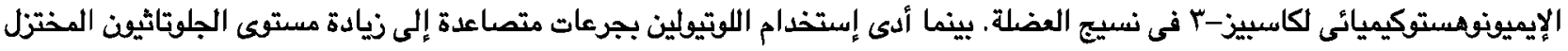

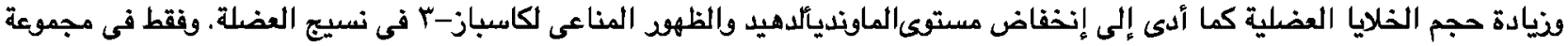

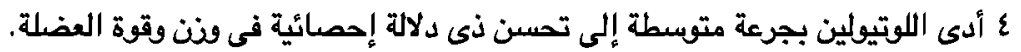

الأستستاجات: هذه النتائج تمهد الطريق لإستخدام اللوتيولين كعلاج وقائى ضد ضمور العضلات الناتج من الجلوكوكوتيكويدات عن طريق

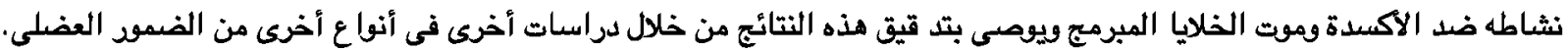

